\title{
Promoter hypermethylation of tissue specific tumor supressor genes and point mutation in K-ras, c-myc proto-oncogenes in urinary (transitional cell) bladder carcinoma
}

\author{
Oztürk Ozdemir ${ }^{1 *}$, Esin Yildiz², Semih Ayan ${ }^{3}$, Eylem Gul ${ }^{1}$, Gökhan Gokce ${ }^{3}$, Fazilet Yildiz ${ }^{1}$, \\ Binnur Koksal ${ }^{1}$
}

\author{
${ }^{1}$ Department of Medical Genetics, Faculty of Medicine, Cumhuriyet University, Sivas, Turkey; ${ }^{*}$ Corresponding Author: \\ ozdemir615@yahoo.com \\ ${ }^{2}$ Department of Pathology, Faculty of Medicine, Cumhuriyet University, Sivas, Turkey \\ ${ }^{3}$ Department of Urology, Faculty of Medicine, Cumhuriyet University, Sivas, Turkey
}

Received 8 November 2009; revised 26 December 2009; accepted 30 December 2009.

\begin{abstract}
In a total of 83 UN specimens were investigated for proto-oncogene mutations, tumor supressor genes promoter methylation status and c-myc and $\mathrm{Ki}-67$ expression. Point mutations in c-myc were detected in cases with high grade and proliferation index. Mutated K-ras proto-oncogene profiles were detected in $17(21 \%)$ tumoral spiecemens that examined. Tumor specimens were also showed hypermethylated promoter domain for the SFRP2, MGMT tumor supressor genes. These findings showed the combine effect of mutated c-myc and K-ras oncogene and epigenetic inactivation of tissue specific tumor supressor genes (TS) play a crucial role in tumor progression and recurrence in UN carcinogenesis.
\end{abstract}

Keywords: C-myc; K-ras; Ki-67; Urinary Bladder; Urothelial Neoplasms; Promoter Hypermethylation; Tumor Supressor Genes

\section{INTRODUCTION}

The urothelial (transitional cell) neoplasms (UNs) of the urinary bladder are diseases of the entire urothelium characterized and caused by multiple parameters. The molecular events in cancer reveal that histopathologically identical tumors may arise through different molecular mechanisms such as instable genom, tumor suppressor gene inactivation, proto-oncogene activation, chromosomal rearrangements, point mutations, instability of the microsatellite DNA resulting from deficient
DNA repair and multiple epigenetic alterations [1]. Oncoproducts that expressed from active oncogenes play crucial role in eukaryotic cell transformation. The c-myc proto-oncogene encodes a nuclear transcription factors that playing an important role in the regulation of cell proliferation, cell differentiation, cancer initiation and progression [2]. K-ras is the other well known protooncogene that encodes a cytoplasmic guanine nucleotide binding protein and transduces external signals to the nucleus. Acquired missense mutations in codons 12, 13 and 61 , in or near the guanine nucleotide binding domain of K-ras, have transforming potential upon the oncogene by locking the RAS protein into a conformation that promoted the continued stimulation of cell growth [3]. Mutational hot spots were reported in K-ras with high frequency in variety of cancer types including lung, breast, colorectal carcinoma (CRC) and pancreas cell carcinomas [4-6]. As indicated by some researchers the epigenetic alterations play important role in carcinogenesis, tumor invasion and metastasis [7,8]. Transitional cell carcinomas of UNs have diverse molecular and functional characteristics. In the last decade, aberrations in DNA methylation patterns have been accepted to be a common feature of human cancer [9]. Promoter hypermethylation of $\mathrm{CpG}$ islands of some tumor suppressor genes is strongly associated with tumor development and discriminated the tumors in a case and organspecific manner. Tumor suppressor SFRP2 promoter hypermethylation has been reported for some cancer types such as bladder, breast, gastric, hepatocellular carcinoma and renal cell carcinomas [10-12]. In bladder cancers, hypermethylation of the SFRP genes occurs more often in active smokers and is a strong predictor of poor patient survival [12]. Promoter hypermethylation of 
MGMT (O-6-methylguanine-DNA methyl transferase) prevents the removal of groups at the $\mathrm{O}^{6}$ position of guanine, leads to G-A transition in genome [13]. HIC1 is a zinc finger transcriptional repressor activated by $\mathrm{P} 53$ and represses transcription of genes which activated by E2F [14]. The other tumor suppressor gene, DAPK1 encodes a calcium calmoduline dependent protein kinase and induces apoptosis positively [15]. Constitutive activation of K-ras and other oncogenes such as c-myc and E2F stimulate DAPK1 activation [16,17].

In the current study, we aimed to investigate the effect of mutated proto-oncogenes K-ras, c-myc and promoter hypermethylation of some cancer-associated tumor suppressor genes in urinary bladder carcinomas. The association between c-myc, Ki-67 expressions and tumoral recurrence were also aimed to investigate immunohistochemically.

\section{MATERIALS AND METHODS}

\subsection{Patient and Biological Specimens}

The current study was approved by the Research Ethical Committee of Faculty of Medicine of Cumhuriyet University. The first part of the current study was designed to investigate the correlation between c-myc and Ki-67 expressions and cell proliferation, tumor grade, stage and recurrence. Fresh and paraffin-embedded tumoral tissue samples from 83 patients underwent transurethral resection $(n=78)$ and radical cystectomy $(n=5)$ at the Department of Urology for UNs of the urinary bladder between January 1997 and December 2008 were used in the current study. Cases that were found to have new tumoral growth in the cystoscopy after the 3 months following the tumor resection were evaluated as recurrent tumors. The recurrent tumors in a high histological grade and/or pathological stage were evaluated as progressive tumors. To detect the recurrence and/or progression in a total of 56 patients were followed up with 3-6 months of intervals for the first 3 years. Twenty seven patients were lost during the current follow up. The tumor samples were graded histologically based on the WHO/ISUP and staged according to the TNM classification $[15,16]$. All fresh and paraffin-embedded specimens were used for detecting promoter methylation status for some target TS and point mutations in c-myc, $\mathrm{K}$-ras proto-oncogenes.

\subsection{Immunostaining Procedure and Evaluation}

All fresh and paraffin-embedded samples were analised by immunohistochemical staining procedure for $\mathrm{Ki}-67$ and c-myc evaluation was performed with the avidinbiotin-peroxidase (ABP) method. Immunostaining was independently evaluated by three pathologist, and discordances were resolved in a common reading. The samples were fixed in $10 \%$ buffered formalin $(\mathrm{pH}=7.0)$ and embedded in parafin wax. Sections $(5-\mu \mathrm{m})$ were used for hematoxylin and eosin (H\&E) staining for histological evaluation, and for immunostaining with c-myc and Ki-67 antibody. The immunohistochemical studies were scored as follows. The Ki-67 Labeling Index (LI) and c-myc were expressed as percentages of the Ki-67 and c-myc positive cells by counting at least 1000 tumor cells at 400X magnification.

\subsection{SSCP Analysis}

The PCR-SSCP (single strand conformation polymorphism) genotyping was done according to the basic protocol. Sections (10 $\mu \mathrm{m}$ thick) from all UN specimens were used for genomic DNA isolation, in vitro gene amplification and epigenetic analysis. Total genomic DNA was isolated by the nucleospin kit extraction technique (Invitrogene, Germany) according to the basic DNA isolation protocol with some modification [17]. Primers for exon 2 of c-myc oncogene were obtained from MWGBiotech CimbH Paris/FRANCE. Amplifications of exon 2 of c-myc gene were performed in a volume of $50 \mu \mathrm{l}$ reaction mixtures containing $200 \mu \mathrm{M}$ dNTPs (MBI, Fermentas), $0.5 \mu \mathrm{M}$ primers, $30 \mathrm{ng}$ template DNA, $10 \times$ Taq DNA polymerase buffer, $1.5 \mathrm{U} \mu \mathrm{l}$ Taq DNA polymerase (Boehringer, Mannheim) for 35 cycles in Amplitron I DNA Thermal Cycler (Thermolyne) under the following conditions: denaturation at $96^{\circ} \mathrm{C}$ for $30 \mathrm{sec}-$ onds, annealing at $55^{\circ} \mathrm{C}$ for 30 seconds and extention at $72^{\circ} \mathrm{C}$ for 30 seconds.

\subsection{Analysis of Mutation Status of the K-ras Oncogene and Methylation Status of the Promoter Region of TS Genes}

After total genomic DNA isolation the target genes were modified by sodium bisulfite technique and promoter methylation status was determined. Direct in vitro amplification of codons 12 and 13 of proto-oncogene K-ras and promoter methylation status for SFRP2, p16, DAPK1, HIC1 and MGMT were performed by multiplex PCR based stripAssay reverse hybridisation analysis (Vienalab). PCR was performed in a Perkin Elmer 9600 and the profile consisted of an initial melting step of 2 minutes at $94^{\circ} \mathrm{C}$; followed by 35 cycles of $30 \mathrm{sec}$ onds at $94^{\circ} \mathrm{C}, 30$ seconds at $61^{\circ} \mathrm{C}$, and 30 seconds at $72^{\circ} \mathrm{C}$; and a final elongation step of 7 minutes at $72^{\circ} \mathrm{C}$. The mutation analysis was performed by stripAssay technique (Vienna Lab, StripAssay $\mathrm{GmbH}$, Austria) which is based on the reverse-hybridization principle automatically. DNA methylation patterns in the promoter $\mathrm{CpG}$ islands were determined in tumoral tissue samples by methylation-specific PCR (MSP) following the bisul- 
fite modification of isolated genomic DNA.

\subsection{Statistical Analysis}

Statistical analysis of immunostaining findings was performed by One-Way ANOVA (Kruskal Wallins test) for tumor grade and stage, by Mann Whithney U test from two-dependent-samples tests for recurrence and progression and/or to high grade and stage, and by Pearson rank correlation to show the relationship between Ki-67 LI and c-myc expression. The recorded data was independently processed by a biostatistician and performed using SPSS software (RE10.0; SPSS, INC., Chicago, IL). Univariate analysis was done using simple linear regression analysis in relation to recurrence and progression. Multivariate analysis was done using multiple regression analysis. A $p$ value of $<0.05$ was considered statistically significant.

\section{RESULTS}

\subsection{Clinicopathologic Data and Follow-Up Knowledge}

In a total of $83 \mathrm{UN}$ tumors were examined in the current study. Tumors grade were; 6 papilloma, 14 papillary neoplasm of low malignant potential, 22 low grade papillary carcinoma and 41 cases with high grade papillary carcinoma. The stages of tumors that investigated were; 36 in pTa, 20 in pT1 and 27 cases were in pT2. Complete follow-up was obtained for $56(67.4 \%)$ of $83 \mathrm{UN}$ patients. Forty four of 56 patients $(78.5 \%)$ had recurrence. Two $(4.5 \%)$ of that reccurent 44 tumors had progression into both high grade and stage and 42 tumors $(95.5 \%)$ were in high grade and/or stages.

\subsection{Immunostaining and Statistical Analysis of the Results}

The c-myc and Ki-67 expression was not observed in normal control tissues $(\mathrm{n}=5)$. The Ki-67 expression was detected in all tumoral tissues in different stage and grades. Ki-67 antigen labelling was localized to the nucleus with a fine, strong and homogenous brown granularity (Figure 1). The relationships between progression to high grade and/or stage with tumour grade (respectively, $\mathrm{p}=0.75,0.06$ ) and stage (respectively, $\mathrm{p}=0.75$, 0.06 ) were not statistically significant. But, Ki-67 LI correlated with each one of tumor grade, stage, recurrence and/or progression and presence of invasion ( $p<$ 0.05 ). Positive staining for c-myc was defined as a nuclear and/or cytoplasmic staining pattern of epithelial tumor cells, even if the staining was found diffusely or focally in tumor cells (Figure 2). There was no statistically significant differences were found between c-myc expression and each one of tumor grade, stage, recurrence and/or progression ( $p>0.05)$, (Table 1). The c-myc expression did not correlated with Ki-67 LI ( $\mathrm{r}=$ $-0.06, p=0.587 ; p>0.05)$ as well. In univariate analysis, higher tumor stage $(p=0.0001)$ and grade $(p=0.0001)$

Table 1. The mean values of c-myc and Ki-67 expression in the cases with UN in relation to variables (with Kruskal Wallins test for tumor grade and stage, Mann Whithney U test for tumoral recurrence, progression to high grade and/or stage).

\begin{tabular}{|c|c|c|c|c|}
\hline Variables & $\begin{array}{c}\text { Ki-67, LI } \\
\text { (mean\% } \pm \\
\text { Std.deviation) }\end{array}$ & $\begin{array}{l}\text { P value in relation to } \\
\text { Ki-67 expression }\end{array}$ & $\begin{array}{c}\text { c-myc } \\
\text { (mean\% } \pm \\
\text { Std.deviation) }\end{array}$ & $\begin{array}{l}\text { P value in relation to } \\
\text { c-myc expression }\end{array}$ \\
\hline $\begin{array}{l}\text { WHO/ISUPGrade } \\
\text { Papillom }(n=6) \\
\text { UN of LMP }(n=14) \\
\text { LGUC }(n=22) \\
\text { HGUC }(n=41)\end{array}$ & $\begin{array}{c}1.83 \pm 0.40 \\
5.07 \pm 1.81 \\
11.36 \pm 3.82 \\
30.60 \pm 9.30\end{array}$ & 0.0001 & $\begin{array}{c}11.00 \pm 8.24 \\
11.85 \pm 10.05 \\
9.13 \pm 8.71 \\
7.09 \pm 7.37\end{array}$ & 0.261 \\
\hline $\begin{array}{l}\text { pT stage } \\
\text { pTa }(n=36) \\
\text { pT1 }(n=20 \\
\text { pT2 }(n=27)\end{array}$ & $\begin{array}{c}8.91 \pm 7.77 \\
19.45 \pm 10.03 \\
32.48 \pm 9.79\end{array}$ & 0.0001 & $\begin{array}{c}10.55 \pm 10.10 \\
6.80 \pm 5.21 \\
7.70 \pm 7.32\end{array}$ & 0.203 \\
\hline $\begin{array}{l}\text { Tumoural recurrence in } 56 \text { patients } \\
\text { with follow up } \\
\text { Absent }(n=12) \\
\text { Presence }(n=44)\end{array}$ & $\begin{array}{c}4.00 \pm 2.92 \\
23.09 \pm 14.09\end{array}$ & 0.0001 & $\begin{array}{c}11.08 \pm 7.64 \\
8.59 \pm 9.13\end{array}$ & 0.158 \\
\hline $\begin{array}{l}\text { Progression to high grade in } 44 \text { tu- } \\
\text { mours with recurrence } \\
\text { Absent }(n=27)\end{array}$ & $\begin{array}{c}2.50 \pm 0.70 \\
10.64 \pm 3.85\end{array}$ & 0.023 & $\begin{array}{l}11.50 \pm 12.02 \\
10.82 \pm 11.53\end{array}$ & 0.842 \\
\hline $\begin{array}{l}\text { Presence }(\mathrm{n}=17) \\
\text { Progression to high stage in } 44 \text { tu- } \\
\text { mours with recurrence } \\
\text { Absent }(\mathrm{n}=34) \\
\text { Presence }(\mathrm{n}=10)\end{array}$ & $\begin{array}{l}17.00 \pm 14.84 \\
24.88 \pm 13.57\end{array}$ & 0.062 & $\begin{array}{l}7.80 \pm 9.19 \\
8.82 \pm 9.23\end{array}$ & 0.546 \\
\hline
\end{tabular}

LI, labelling index; UN of LMP, urothelial neoplasm of low malignant potential; LGUC, low grade urothelial carcinoma; HGUC, high-grade urothelial carcinoma. 
were associated with higher recurrence ratio. In a multivariate analysis including the factors tumor grade and stage, c-myc and Ki-67 expression, independent prognostic value was seen tumor grade for recurrence $(\mathrm{p}<$ $0.0001)$, the Ki-67 expression was statistically significant $(p<0.0001)$ for progression to high tumor grade. No factor had independent prognostic value for progression to high tumor stage in the current results.

\subsection{Analysis of Exon 2 of $\mathrm{C}$-myc and Codon 12-13 of K-ras Proto-Oncogenes}

The mechanism underlying c-myc expression was further investigated in 54 bladder tumor samples. The exon

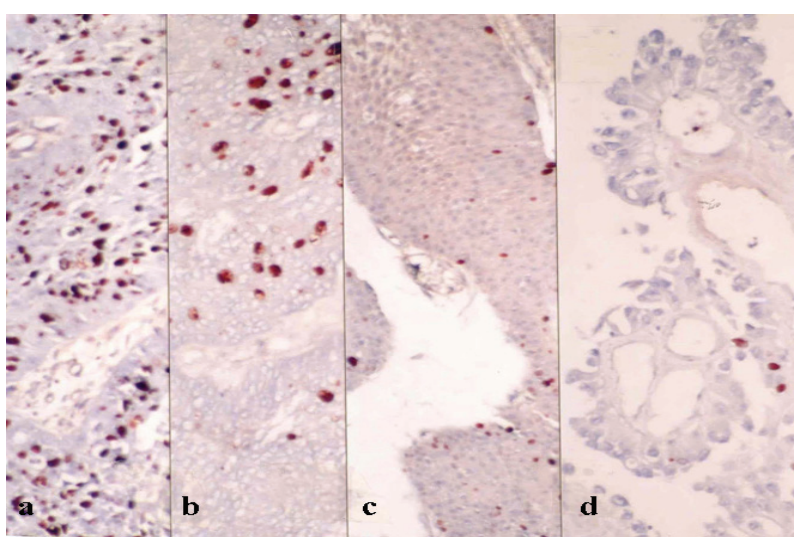

Figure 1. A fine, strong and homogenous brown granularity in the nuclei of the tumoral cells with Ki-67 antibody (Avidin Biotine Peroxidase tecnique, $\times 150$ ). (a) High-grade papillary carcinoma; (b) Low-grade papillary carcinoma; (c) Low malignant potential papillary neoplasm; (d) Papilloma.

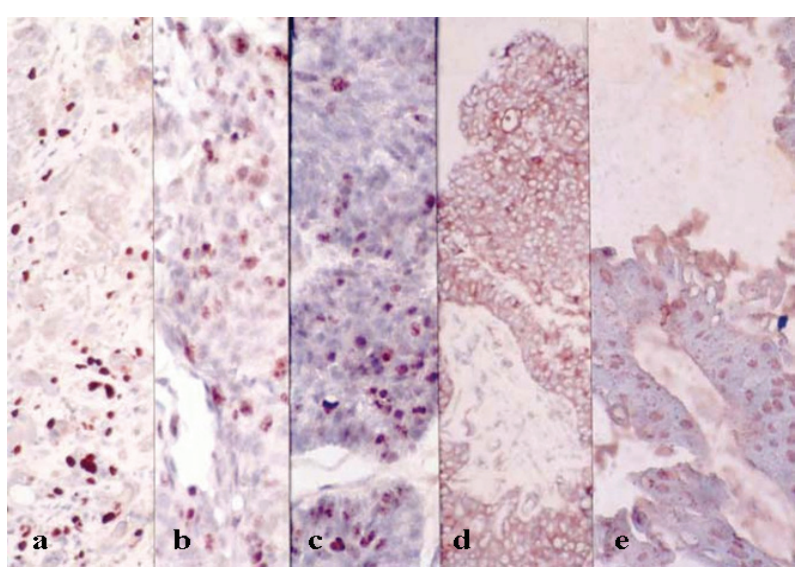

Figure 2. A nuclear and/or cytoplasmic staining pattern of epithelial tumor cells for c-myc antibody (Avidin Biotine Peroxidase tecnique, $\times 150$ ); (a) Both nuclear and cytoplasmic staining in high-grade urothelial carcinoma; (b) Low-grade urothelial carcinoma; (c) Nuclear staining in low malignant potential urothelial neoplasm; (d) Cytoplasmic staining in low malignant potential urothelial neoplasm; (e) Nuclear staining in papilloma.
2 of c-myc gene was found mutated in one case which is in high grade and advanced stage of bladder cancer (Figure 3, arrow). Mutated KRAS proto-oncogene profiles were detected in $17(21 \%)$ tumoral specimens that examined. Ten point mutations were detected in codon 13 Asp (Figure 4, lane 1), 5 were in codon12 Val and 2 point mutations were in codon 12 Asp.

\subsection{Promoter Hypermethylation Profiles in Tumor Suppressor Genes}

Clinic, promoter hypermethylation profiles, histopathological and molecular parameters in bladder cancer of current 83 UNs samples showed a high sensitivity and a specificity. Tumor specimens were showed fully promoter hypermethylation for MGMT(66\%), SFRP2(44\%) and partially inactivation for other tumor suppressor genes that examined. In general no epigenetic alterations

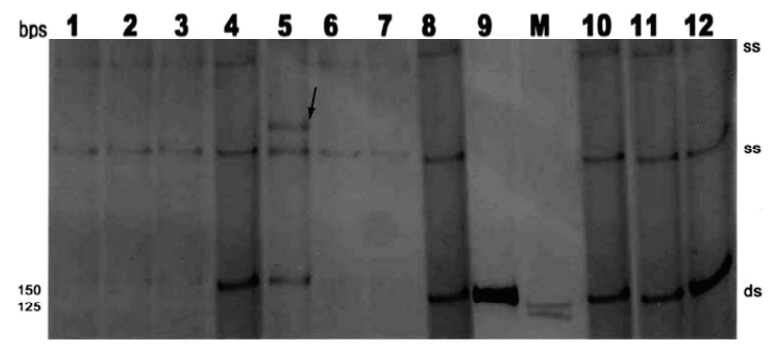

Figure 3. SSCP profiles of exon 2 of $c$-myc proto-oncogene in human bladder's papillary urothelial (transitional cell) neoplasm tissues. Arrow indicates mutated single strand (ss). ds: double strand.

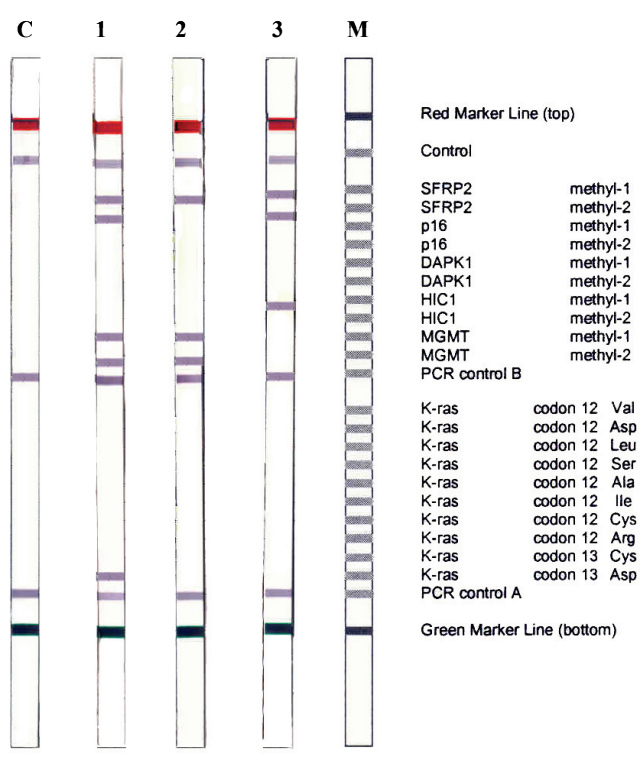

Figure 4. Shows epigenetically modified profiles of the TS genes of SFRP2, p16, DAPK1, HIC1, MGMT and point mutations in codon 12 and 13 of proto-oncogene K-ras in control and tumoral tissue samples of the current UN samples. 
Table 2. Promoter hypermethylation status of distinct tissue specific tumor supressor genes according to the tumoral grades.

\begin{tabular}{|c|c|c|c|c|c|}
\hline \multirow[b]{2}{*}{$\begin{array}{c}\text { Tumor } \\
\text { Supressor } \\
\text { Type }\end{array}$} & \multirow[b]{2}{*}{$\begin{array}{l}\text { Epigenetic } \\
\text { Profile }\end{array}$} & \multicolumn{4}{|c|}{$\begin{array}{c}\text { WHO/ISUP Grade } \\
\text { Total }=83\end{array}$} \\
\hline & & $\begin{array}{c}\text { Papillom } \\
(\mathrm{n}=6) \\
\mathrm{n} \\
\%\end{array}$ & $\begin{array}{c}\text { UN of } \\
\text { LMP } \\
(\mathbf{n}=\mathbf{1 4}) \\
\mathbf{n} \\
\%\end{array}$ & $\begin{array}{c}\text { LGUC } \\
(\mathbf{n}=\mathbf{2 2}) \\
\mathbf{n} \\
\%\end{array}$ & $\begin{array}{c}\text { HGUC } \\
(\mathrm{n}=41) \\
\mathrm{n} \\
\%\end{array}$ \\
\hline \multirow{3}{*}{ SFRP2 } & $\begin{array}{l}\text { Unmethylated, } \\
\text { active gene }\end{array}$ & $\begin{array}{c}6 \\
100\end{array}$ & $\begin{array}{l}11 \\
79\end{array}$ & $\begin{array}{l}11 \\
50\end{array}$ & $\begin{array}{c}9 \\
22\end{array}$ \\
\hline & $\begin{array}{c}\text { Partially } \\
\text { methyleted- } \\
\text { heterozygous } \\
\text { inactive gene }\end{array}$ & $\begin{array}{l}- \\
-\end{array}$ & $\begin{array}{c}2 \\
14\end{array}$ & $\begin{array}{c}6 \\
27\end{array}$ & $\begin{array}{l}14 \\
34\end{array}$ \\
\hline & $\begin{array}{l}\text { Fully methyleted, } \\
\text { inactive gene }\end{array}$ & $\begin{array}{l}- \\
-\end{array}$ & $\begin{array}{l}1 \\
7\end{array}$ & $\begin{array}{c}5 \\
23\end{array}$ & $\begin{array}{l}18 \\
44\end{array}$ \\
\hline \multirow{3}{*}{ p16 } & $\begin{array}{l}\text { Unmethylated, } \\
\text { active gene }\end{array}$ & $\begin{array}{c}6 \\
100\end{array}$ & $\begin{array}{c}14 \\
100\end{array}$ & $\begin{array}{c}22 \\
100\end{array}$ & $\begin{array}{l}39 \\
95\end{array}$ \\
\hline & $\begin{array}{c}\text { Partially } \\
\text { methyleted- } \\
\text { heterozygous } \\
\text { inactive gene }\end{array}$ & $\begin{array}{l}- \\
-\end{array}$ & $\begin{array}{l}- \\
-\end{array}$ & - & $\begin{array}{l}2 \\
5\end{array}$ \\
\hline & $\begin{array}{l}\text { Fully methyleted, } \\
\text { inactive gene }\end{array}$ & $\begin{array}{l}- \\
-\end{array}$ & $\begin{array}{l}- \\
-\end{array}$ & $\begin{array}{l}- \\
-\end{array}$ & $\begin{array}{l}- \\
-\end{array}$ \\
\hline \multirow{3}{*}{ DAPK1 } & $\begin{array}{l}\text { Unmethylated, } \\
\text { active gene }\end{array}$ & $\begin{array}{c}6 \\
100\end{array}$ & $\begin{array}{c}14 \\
100\end{array}$ & $\begin{array}{l}21 \\
95\end{array}$ & $\begin{array}{l}38 \\
93\end{array}$ \\
\hline & $\begin{array}{c}\text { Partially } \\
\text { methyleted- } \\
\text { heterozygous } \\
\text { inactive gene }\end{array}$ & $\begin{array}{l}- \\
-\end{array}$ & $\begin{array}{l}- \\
-\end{array}$ & $\begin{array}{l}- \\
-\end{array}$ & $\begin{array}{l}3 \\
7\end{array}$ \\
\hline & $\begin{array}{l}\text { Fully methyleted, } \\
\text { inactive gene }\end{array}$ & $\begin{array}{l}- \\
-\end{array}$ & $\begin{array}{l}- \\
-\end{array}$ & $\begin{array}{l}1 \\
5\end{array}$ & $\begin{array}{l}- \\
-\end{array}$ \\
\hline \multirow{3}{*}{ HIC1 } & $\begin{array}{l}\text { Unmethylated, } \\
\text { active gene }\end{array}$ & $\begin{array}{c}6 \\
100\end{array}$ & $\begin{array}{l}12 \\
86\end{array}$ & $\begin{array}{l}19 \\
86\end{array}$ & $\begin{array}{l}24 \\
59\end{array}$ \\
\hline & $\begin{array}{c}\text { Partially } \\
\text { methyleted- } \\
\text { heterozygous } \\
\text { inactive gene }\end{array}$ & - & $\begin{array}{c}2 \\
14\end{array}$ & $\begin{array}{c}3 \\
14\end{array}$ & $\begin{array}{l}14 \\
34\end{array}$ \\
\hline & $\begin{array}{l}\text { Fully methyleted, } \\
\text { inactive gene }\end{array}$ & $\begin{array}{l}- \\
-\end{array}$ & $\begin{array}{l}- \\
-\end{array}$ & $\begin{array}{l}- \\
-\end{array}$ & $\begin{array}{l}3 \\
7\end{array}$ \\
\hline \multirow{3}{*}{ MGMT } & $\begin{array}{l}\text { Unmethylated, } \\
\text { active gene }\end{array}$ & $\begin{array}{c}5 \\
83\end{array}$ & $\begin{array}{l}11 \\
79\end{array}$ & $\begin{array}{c}9 \\
41\end{array}$ & $\begin{array}{c}7 \\
17\end{array}$ \\
\hline & $\begin{array}{c}\text { Partially } \\
\text { methyleted- } \\
\text { heterozygous } \\
\text { inactive gene }\end{array}$ & $\begin{array}{c}1 \\
17\end{array}$ & $\begin{array}{c}2 \\
14\end{array}$ & $\begin{array}{c}6 \\
28\end{array}$ & $\begin{array}{c}7 \\
17\end{array}$ \\
\hline & $\begin{array}{l}\text { Fully methyleted, } \\
\text { inactive gene }\end{array}$ & $\begin{array}{l}- \\
-\end{array}$ & $\begin{array}{l}1 \\
7\end{array}$ & $\begin{array}{c}7 \\
31\end{array}$ & $\begin{array}{l}27 \\
66\end{array}$ \\
\hline
\end{tabular}

TS, tumor supressor; SFRP2, secreted frizzled-related protein 2; p16, death-associated protein kinase 2; DAPK1, death-associated protein kinase 1; HIC1 hypermethylated in cancer 1; MGMT, O-6- methylguanine-DNA methyltransferase were detected in papilloma and LMP type tumors but heterogenous type alterations were detected in LGUC tumors (Table 2). Tumor supressor p16, DAPK1 and HIC1 were showed partially inactivation in HGUC tumors but fully active profiles in papilloma and other two tumors that were in early stages (Table 2). The current results showed fully inactivation (homozygous of both allels) of SFRP2 and MGMT genes in especially in UN tumors that HGUC stage (Figure 4, lanes 1-3, Table 2). Normal active gene profiles (unmethylated) were detected in healthy control group tissue for all studied TS genes(blood) and no point mutation was detected in c-myc (Figure 3, lanes 1-4) and K-ras proto-oncogenes (Figure 4, lane $\mathrm{C}$ ).

\section{DISCUSSION}

$\mathrm{UN}$ of the bladder is the second most common tumors of the genitourinary tract and causes the second highest number of deaths of all genitourinary tumors [18]. The risk of recurrence in these patients after transurethral resection and intravesical chemotherapy and/or immunotherapy occures between $33-70 \%$ [19]. As many as $20-30 \%$ of these recurrent tumors was found to have progressed to a higher histological grade and/or pathological stage $[19,20]$. However, it is not possible to make accurate assumptions on a patient's clinical outcome in regards to prognosis simply by considering the grade and stage of the tumor. Latest progressions in epigenetic methodologies and gene silencing techniques opened a new area for the identification of epigenetic parameters, which appears to be more useful for UNs and other tumoral cell diagnosis and prognosis. Previous studies have shown an association between cell proliferation and tumor grade, stage and prognosis in bladder carcinoma [21-23]. Nowadays, biomarkers that reported for UNs have not shown sufficient sensitivity and specificity in routine clinical practice in particular, the high-risk patient groups that are at risk of progression and recurrence [24]. In the present study, a significant correlation was found between Ki-67 expression and tumor grade, stage, recurrence and/or progression. As claimed by Kim and $\mathrm{Bae}$, the promoter silencing of TS genes is most important phenomenon that plays tumor specific effect in urinary bladder due to reverse epigenetic changes $[24,25]$.

Marsit and co-workers were examined the relationship between epigenetic silencing of three TS genes, p16 (INK4A), RASSF1A and PRSS3 in a population-based study of human bladder cancer. They were reported that the promoter hypermethylation status of each gene was detected in approximately $30 \%$ of bladder cancers [10]. Our results confirmed the association between gene hypermethylation status and advance tumoral differentiations. Tumoral specimen showed fully methyl pattern 
profiles for the SFRP2, MGMT and partially hypermethylated profile for the HIC1, p16 and DAPK1 genes in different ratios according to the tumor grade in the current results (Table 2, Figure 4).

The current results also showed the structural mutations in exon 2 of c-myc and codons 12, 13 of the K-ras proto-oncogenes in high grade and advanced stage of UN tumors. No correlation was found between c-myc structural mutation and overexpression and tumor grade, stage, recurrence, progression and/or invasion in the current results. With a high-throughput tissue specific microarray analysis Zaharieva et al. showed that the alterations of the c-myc gene was linked to genetically unstable bladder cancers that are characterized by a high histologic grade and/or invasion [26]. Using fluorescence in situ hybridization (FISH), Mahdy et al. observed a correlation bettween c-myc copy number gain and bladder cancer grade and stage [27]. On the other hand Schmitz-Dräger et al. were not reported any correlation between c-myc overexpression and tumor grade and stage in 185 paraffin-embedded urothelial tissue specimens by using immunohistochemical analysis [28].

Our results confirm that UNs have a heterogeneous cell profiles, multiple molecular factors are likely to be involved in tumor recurrence and progression. It has also been verified that combine molecular biomarkers such as epigenetic alterations and proto-oncogene point mutations widely occur at a late stage of the invasive HGPC tumors. The fully and/or partially silencing through promoter region of SFRP2 and MGMT have a potential clinical implications as a UNs tumor progression and good target for the development of new therapeutic approaches such as adjuvant therapies with demethylating agents. So we claimed that the tumoral tissue specific idendification extremely need for the patient's survival.

\section{ACKNOWLEDGEMENTS}

The current project was supported by basic research fund of Cumhuriyet University (CUBAP). Authors want to thank to A. Sahin, F. Bektaş and Z. CINAR for their kindly technical assistance.

\section{REFERENCES}

[1] Guo, M., Pollan, M., Herman, J.G. and Esteller, M. (2003) A systematic profile of DNA methylation in human cancer cell lines. Cancer Research, 63(5), 1114-1123.

[2] Nesbit, C.E., Tersak, J.M. and Procchownık, E.V. (1999) MYC oncogenes and human neoplastic disease. Oncogene, 18(9), 3004-3016.

[3] Plesec, T.P. and Hunt, J.L. (2009) KRAS mutation testing in colorectal cancer. Advances in Anatomic Pathology, 16(4), 196-203.

[4] Heinemann, V., Stintzing, S., Kircher, T. and Jung, A.
(2009) Clinical relevance of EGFR and KRAS status in colorectal cancer patients treated with monoclonal antibodies directed against the EGFR. Cancer Treatment Reviews, 35(3), 262-271.

[5] Schmid, K., Oehl, N., Wrba, F., Pirker, R., Pirker, C. and Filipits, M. (2009) EGFR/KRAS/BRAF mutations in primary lung adenocarcinomas and corresponding locoregional lymph node metastases. Clinical Cancer Research, 15(14), 4554-4560.

[6] Bournet, B., Souque, A., Senesse, P., Assenat, E., Barthet, M., Lesavre, N., Aubert, A., O’Toole, D., Hammel, P., Levy, P., Ruszniewski, P., Bouisson, M., Escourrou, J., Cordelier, P. and Buscail, L. (2009) Endoscopic ultrasound-guided fine-needle aspiration biopsy coupled with KRAS mutation assay to distinguish pancreatic cancer from pseudotumoral chronic pancreatitis. Endoscopy, 41(6), 552-557.

[7] Ellis, L., Atadja, P.W. and Johnstone, R.W. (2009) Epigenetics in cancer: Targeting chromatin modifications. Molecular Cancer Therapeutics, 8(6), 1409-1420.

[8] Ballestar, E. and Esteller, M. (2008) Epigenetic gene regulation in cancer. Advances in Genetics, 61, 247-267.

[9] Mueller, W.C. and Von Deimling, A. (2009) Gene regulation by methylation. Recent Results in Cancer Research, 171, 217-239.

[10] Marsit, C.J., McClean, M.D., Furniss, C.S. and Kelsey, K.T. (2006) Epigenetic inactivation of the SFRP genes is associated with drinking, smoking and HPV in head and neck squamous cell carcinoma. International Journal of Cancer, 119(8), 1761-1766.

[11] Nojima, M., Suzuki, H., Toyota, M., Watanabe, Y., Maruyama, R., Sasaki, S., Sasaki, Y., Mita, H., Nishikawa, N., Yamaguchi, K., Hirata, K., Itoh, F., Tokino, T., Mori, M., Imai, K. and Shinomura, Y. (2007) Frequent epigenetic inactivation of SFRP genes and constitutive activation of Wnt signaling in gastric cancer. Oncogene, 26(32), 4699-46713.

[12] Shih, Y.L., Hsieh, C.B., Lai, H.C., Yan, M.D., Hsieh, T.Y., Chao, Y.C. and Lin, Y.W. (2007) SFRP1 suppressed hepatoma cells growth through Wnt canonical signaling pathway. International Journal of Cancer, 121(5), 10281035.

[13] Krtolica, K., Krajnovic, M., Knezevic, S.U., Babic, D., Jovanovic, D. and Dimitriyevic, B. (2007) Comethilation of P16 and MGMT genes in colorectal carcinoma: Correlation with clinopathological features and prognostic value. World Journal of Gastroenterology, 28(13), 1187 1194.

[14] Wales, M.M., Biel, M.A., Deiry, W., Nelkin, B.D., Issa, J.P., Cavenee, W.K., Kuerbitz, S.J. and Baylin, S.B. (1995) p53 activates expression of HIC-1, a new candidate tumour suppressor gene on $17 \mathrm{p} 13.3$. Nature Medicine, 1(6), 570-577.

[15] Lin, Y., Stevens, C., Harrison, B., Pathuri, S., Amin, E. and Hupp, T.R. (2009) The alternative splice variant of DAPK-1, s-DAPK-1, induces proteasome-independent DAPK-1 destabilization. Molecular and Cellular Biochemistry, 328(1-2), 101-107.

[16] Anjum, R., Roux, P.P., Ballif, B.A., Gygi, S.P. and Blenis, J. (2005) The tumor suppressor DAP kinase Is a target of RSK-mediated survival signaling. Current Biology, 15(9), 1762-1767. 
[17] Raveh, T. and Kimchi, A. (2001) DAP kinase-A proapoptotic gene that functions as a tumor suppressor. Experimental Cell Research, 264(1), 185-192.

[18] Baffa, R., Letko, J., McClung, C., LeNorr, J., Vecchione, A. and Gomella, L.G. (2006) Molecular genetics of bladder cancer: Targets for diagnosis and therapy. Journal of Experimental and Clinical Cancer Research, 25(2), 145-160.

[19] Hasui, Y., Osada, Y., Kitada, S. and Nishi, S. (1994) Significance of invasion to the muscularis mucosae on the progression of superficial bladder cancer. Urology, 43(6), 782-786.

[20] Yeh, C.W., Huang, S.S., Lee, R.P. and Yung, B.Y. (2006) Ras-Dependent Recruitment of c-myc for Transcriptional Activation of Nucleophosmin/B23 in Highly Malignant U1 Bladder Cancer Cells. Molecular Pharmacology, 70(4), 1443-1453.

[21] Fontana, D., Bellına, M., Gubetta, L., Fasolis, G., Rolle, L., et al. (1992) Monoclonal antibody Ki-67 in the study of proliferative activity of bladder carcinoma. The Journal of Urology, 148(4), 1149-1151.

[22] Helpap, B. and Kollerman, J. (2000) Assessment of basal cell status and proliferative patterns in flat and papillary urothelial lesions: A contribution to the new WHO classification of urothelial tumors of the urinary bladder. $\mathrm{Hu}$ man Pathology, 31(6), 745-750.
[23] Kojıma, K., Murakamı, Y., Kanayama, H. and Kagawa. (1997) Prognostic value of Ki-67 antigen and p53 protein in urinary bladder cancer: Immunohistochemical analysis of radical cyctectomy specimens. British Journal of Urology, 79(3), 367-372.

[24] Kim, Y.K. and Kim, W.J. (2009) Epigenetic markers as promising prognosticators for bladder cancer. International Journal of Urology, 16(1), 17-22.

[25] Kim, W.J. and Bae, S.C. (2008) Molecular biomarkers in urothelial bladder cancer. Cancer Science, 99(4), 646652.

[26] Zaharieva, B., Simon, R., Ruiz, C., Oeggerli, M., Mihatsch, M.J., Gasser, T., Sauter, G. and Toncheva, D. (2005) High-throughput tissue microarray analysis of CMYC amplificationin urinary bladder cancer. International Journal of Cancer, 117(6), 952-956.

[27] Mahdy, E., Pan, Y., Wang, N., Malmström, P.U., Ekman, P. and Bergerheim, U. (2001) Chromosome 8 numerical aberration and C-MYC copy number gain in bladder cancer are linked to stage and grade. Anticancer Research, 21(5), 3167-3173.

[28] Schmitz-Dräger, B.J., Schulz, W.A., Jürgens, B., Gerharz, C.D., van Roeyen, C.R., Bültel, H., Ebert, T. and Ackermann, R. (1997) C-myc in bladder cancer. Clinical findings and analysis of mechanism. Urological Research, 25(1), 45-49. 